\title{
MR spectroscopy in pediatric Wernicke encephalopathy
}

Figure Brain magnetic resonance with spectroscopy
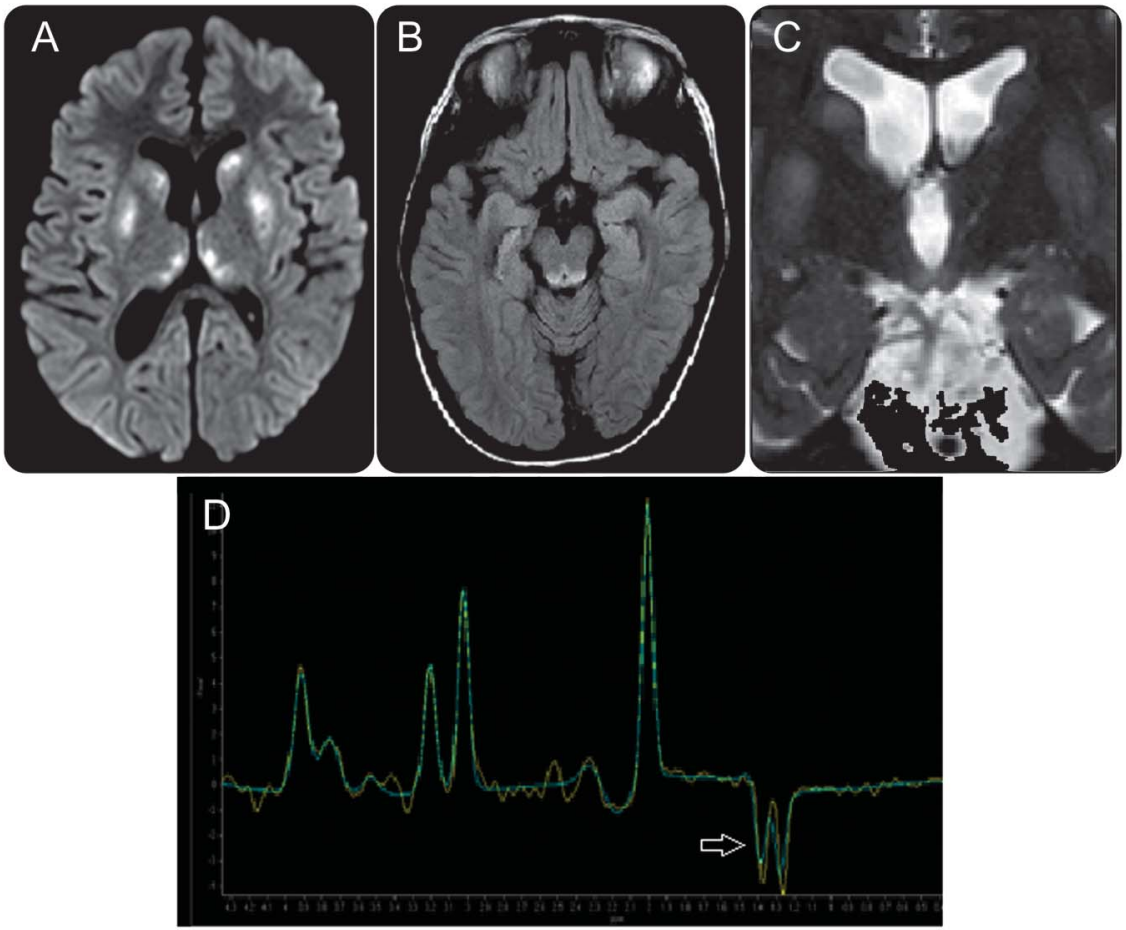

(A) Diffusion restriction in bilateral striata and medial thalami. (B) Increased T2 signal in periaqueductal gray on axial fluid-attenuated inversion recovery. (C) T2 hyperintensities in mamillary bodies on coronal T2. (D) Magnetic resonance spectroscopy demonstrating a large lactate doublet (arrow) at 1.33 ppm (voxels taken from left basal ganglia and left parietal white matter).

The patient is a 7-year-old girl with a history of repaired gastroschisis and short gut syndrome. She presented with a 4-day history of progressive encephalopathy, truncal ataxia, and omnidirectional gaze-evoked nystagmus. Peripheral lactate was $7.1 \mathrm{mmol} / \mathrm{L}$. Serum thiamine level was decreased $(<5 \mathrm{nmol} / \mathrm{L})$. Brain magnetic resonance with spectroscopy is shown in the figure. A clinical diagnosis of Wernicke encephalopathy was made. The patient was started on thiamine and demonstrated a rapid clinical recovery. Peripheral lactate normalized within 1 day. Increased lactate has been reported in thiamine deficiency, presumed secondary to the role of thiamine as a cofactor for the pyruvate dehydrogenase complex and $\alpha$-ketoglutarate dehydrogenase. ${ }^{1}$

Lance H. Rodan, MD, Navin Mishra, MD, Ingrid Tein, MD, FRCPC

From the Hospital for Sick Children (L.H.R., N.M., I.T.) and University of Toronto (L.H.R., I.T.), Toronto, Canada.

Author contributions: Lance H. Rodan: preparation of manuscript. Navin Mishra: editing of manuscript. Ingrid Tein: editing of manuscript, supervisor.

Study funding: No targeted funding reported.

Disclosure: The authors report no disclosures relevant to the manuscript. Go to Neurology.org for full disclosures.

Correspondence to Dr. Rodan: lance.rodan@utoronto.ca

1. Desjardins P, Butterworth R. Role of mitochondrial dysfunction and oxidative stress in the pathogenesis of selective neuronal loss in Wernicke's encephalopathy. Mol Neurobiol 2005;31:17-25. 


\title{
Neurology
}

\author{
MR spectroscopy in pediatric Wernicke encephalopathy \\ Lance H. Rodan, Navin Mishra and Ingrid Tein \\ Neurology 2013;80;969 \\ DOI 10.1212/WNL.0b013e3182840cd9
}

This information is current as of March 4, 2013

\section{Updated Information \& Services}

\section{References}

Subspecialty Collections

\section{Permissions \& Licensing}

\section{Reprints}

including high resolution figures, can be found at: http://n.neurology.org/content/80/10/969.full

This article cites 1 articles, 0 of which you can access for free at: http://n.neurology.org/content/80/10/969.full\#ref-list-1

This article, along with others on similar topics, appears in the following collection(s):

\section{All Pediatric}

http://n.neurology.org/cgi/collection/all_pediatric

Gastrointestinal

http://n.neurology.org/cgi/collection/gastrointestinal

MRI

http://n.neurology.org/cgi/collection/mri

\section{MRS}

http://n.neurology.org/cgi/collection/mrs

Nutritional

http://n.neurology.org/cgi/collection/nutritional

Information about reproducing this article in parts (figures,tables) or in its entirety can be found online at:

http://www.neurology.org/about/about_the_journal\#permissions

Information about ordering reprints can be found online:

http://n.neurology.org/subscribers/advertise

Neurology ${ }^{\circledR}$ is the official journal of the American Academy of Neurology. Published continuously since 1951, it is now a weekly with 48 issues per year. Copyright (C 2013 American Academy of Neurology. All rights reserved. Print ISSN: 0028-3878. Online ISSN: 1526-632X.

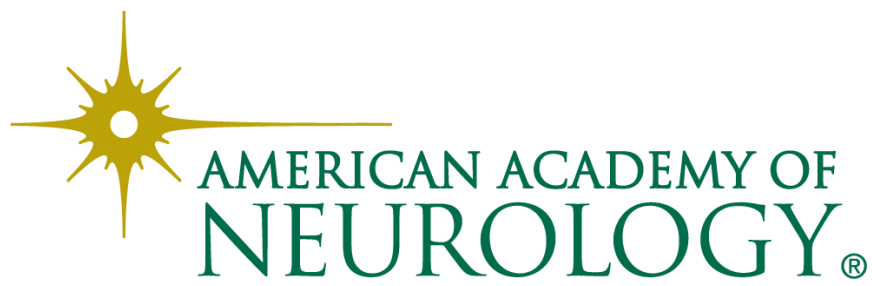

